\title{
MICROSCOPIC AND RADIOGRAPHIC ANALYSIS OF THE EFFECT OF PARTICLE SIZE OF DEMINERALIZED BOVINE CANCELLOUS BONE MATRIX ON THE REPAIR OF BONE DEFECTS IN FEMURS OF RABBITS
}

\author{
ANÁLISE MICROSCÓPICA E RADIOGRÁFICA DO EFEITO DO TAMANHO DAS \\ PARTÍCULAS DE MATRIZ DE OSSO MEDULAR BOVINO DESMINERALIZADO NA \\ REPARAÇÃO DE DEFEITO ÓSSEO EM FÊMURES DE COELHOS
}

Everdan CARNEIRO ${ }^{1}$, Roberto Brandão GARCIA ${ }^{2}$, Rodrigo Cardoso de OLIVEIRA ${ }^{1}$, Fernanda Gomes de MORAES
Renato MENEZES ${ }^{1}$, Ariadne LETRA ${ }^{1}$, Giovana Calichio CANOVA ${ }^{1}$, Tania Mary CESTARI ${ }^{3}$, José Mauro GRANJEIRO ${ }^{4}$

1- DDS, Graduate Student (Master degree) - Bauru Dental School, University of São Paulo.

2- PhD, Full Professor, Endodontics, Department Dental Material, Restorative Dentistry and Endodontics, Bauru Dental School, University of São Paulo.

3- Graduate in Biological Sciences, Department of Oral Sciences, Bauru Dental School, University of São Paulo.

4- PhD, Associate Professor, Department of Biological Sciences, Bauru Dental School, University of São Paulo- SP, Brazil.

Corresponding address: Everdan Carneiro - R. Fernando Machado, 205, ap 201 Centro - Caçador - SC Brasil - Cep.: 89500000

e-mail: everdan@conection.com.br

Received: July 2003 - Modification: January 08, 2004 - Accepted: May 10, 2005

\begin{abstract}
The

Le bone tissue has a great regenerative potential, with ability to completely restore its structure and original functions. In some situations, though, bone defects cannot be self-repaired, thus requiring the use of grafts for a correct treatment and good prognosis. This work aimed at microscopically analyzing the effect of the particle size of demineralized bovine cancellous bone matrix in micro and macrogranular forms on the repair of bone defects in femurs of rabbits, with blood clot used as control. At 1, 3 and 6 months after implantation of the materials, the animals were killed and the anatomic specimens were removed. A foreign body-type granulomatous reaction containing macrophages and multinucleated giant cells in contact with the implanted particles was observed. These results suggest a failure in demineralization and/or interruption of the antigenic potential during production of the biomaterial. It is concluded that the size of the particles did not influence the evolution of the repair process of bone defects, acting only as bone-filler substances, and that the material implanted should be improved by quality control during production, since it may represent a good alternative for bone graft.

Uniterms: Xenogenic graft; Bovine cancellous bone; Particle size; Femur; Rabbit.
\end{abstract}

\section{RESUMO}

$O$

tecido ósseo possui grande potencial regenerativo com capacidade para restaurar completamente sua estrutura e função originais. Há situações em que os defeitos ósseos não conseguem por si só obter o reparo, casos em que se fazem necessários o uso de enxertos, para um correto tratamento e bom prognóstico. Este experimento teve o propósito de analisar microscopicamente o efeito do tamanho das partículas de matriz de osso medular bovino desmineralizado, nas formas micro e macrogranular, na reparação de defeito ósseo em fêmures de coelhos, tendo como controle o coágulo sanguíneo. Após 1,3 e 6 meses da implantação dos materiais, os animais foram mortos e as peças anatômicas removidas. Uma reação granulomatosa tipo corpo estranho, envolvendo as partículas implantadas, foi observada. Estes resultados sugerem falhas na desmineralização e/ou na retirada de potenciais antigênicos durante a produção do biomaterial. Podemos concluir que o tamanho das partículas não influenciou na evolução do processo reparativo dos defeitos ósseos, atuando apenas como substâncias osteopreenchedoras e que o material implantado deverá sofrer um aprimoramento no controle de qualidade na linha de produção, uma vez que poderá representar uma boa alternativa para enxertos ósseos.

Unitermos: Enxerto xenogênico; Osso medular bovino; Tamanho de partícula; Fêmur; Coelhos. 


\section{INTRODUCTION}

The bone tissue, the main component of the skeleton, has the function of protecting and supporting the vital organs because of its stiffness and resistance. Its capacity to be restored is related to the ability of growing factors in directing the stem cells for condrogenesis and osteogenesis, and also to the role played by mechanical forces that stimulate bone remodeling. However, when there is a change or major loss in bone structure, either of traumatic or pathological origin, grafts are often required for a correct treatment and good prognosis.

A new interdisciplinary field has been widely discussed lately: the Tissue Engineering, which aims at developing biological substitutes to restore, maintain or improve the function of several tissues ${ }^{6}$. As a consequence, bone grafts are currently investigated in an attempt to find a safe and efficient biological material.

The advent of new xenogenic biomaterials, as bovine bone, which behave as repair promoters and carriers of bone induction factors, seems to represent the future of reconstruction of bone defects; however, there has been a constant concern with the presentation of these biomaterials as to shape and size. The role of carriers of bone induction factors can be potentially played by bovine cancellous or cortical bone, either macro or microgranular, deproteinized or demineralized, as already shown in clinical studies. Besides supplying a supportive structure and bone conduction, it can also provide a high content of calcium and phosphorus, essential for the new formation of bone tissue ${ }^{3,8}$. Nevertheless, the actual role of the size of these bonesubstitute materials in relation to the cellular answer of the host is yet very controversial.

Many bone substitutes, as the deproteinized bovine bone or densely sintered hydroxyapatites, require long periods to be absorbed, determining a continuous flow of multinucleated giant cells ${ }^{10}$ next to the surfaces of the materials or on the walls of porous implanted materials ${ }^{5}$. The absorption of xenografts as measured by cells is directly related to the speed and amount of newly formed bone ${ }^{1}$.

The concern on the capacity of repair according to the different sizes of bone graft particles is still constant. In this sense, this work aimed at determining the capacity of the tissue response to a demineralized organic bovine cancellous bone matrix in the microgranular (250-1000mm) and macrogranular (1000-2000mm) forms, to promote repair of a surgically created bone defect in femurs of laboratory rabbits.

\section{MATERIALAND METHODS}

\section{Animals}

Twenty-four New Zealand white rabbits(Oryctologos Cunicular L.) were used, of male gender, aged around 180 days and with a medium weight of 3000 grams. The animals were obtained from the Central Animal Laboratory of Bauru
Dental School, USP. The experiment was made in conformity with the Ethical Principles of Animal Experimentation of the Brazilian College of Animal Experimentation (COBEA).

\section{Test material}

The bovine bone organic matrix in micro and macrogranular forms $\left(\mathrm{Gen}-\mathrm{Ox}^{\mathrm{TM}}\right.$, Baumer SA, Ministry of Health registration \#103.455.00001) is a natural biomaterial obtained from bovine cancellous bone. After thorough washing for elimination of blood, fat and any impurities, this material is decalcified and dehydrated by the lyophilization process, which prevents denaturation of the proteins while keeping the active component.

\section{Surgical procedures}

All animals were submitted to surgery in both femurs, under anesthetics by intramuscular injection of Xylazine/ Ketamine (Agribrands Ltda ${ }^{\mathrm{TM}}$, Paulinia- Brazil). After trichotomy and asepsis with aqueous solution of povidoneiodine (PVP- iodine), an incision was performed and a full thickness flap was raised. After complete exposure of the bone surface, a perforation of $5 \mathrm{~mm}$ in diameter and $7 \mathrm{~mm}$ in depth was trephined in both femurs of each animal next to its epiphysis. This procedure was performed under continuous irrigation with saline solution.

Each perforation was filled with particles of organic demineralized bovine cancellous bone matrix in the experimental groups (10 cavities per period) and with clot in the control group (6 cavities per period). In the experimental group, the defects in the left femurs were filled with macrogranular particles (1000-2000mm) while the defects in the right femurs were filled with microgranular particles (250$1000 \mathrm{~mm})$. The musculature was sutured with simple stitches using Vicryl 4.0 (absorbable) suture with nontraumatic needle, while the part corresponding to the derma of the animal was sutured with silk suture 4.0, being removed at seven days after surgery.

The animals received antibiotics Flotril (Enrofloxacina) $2.5 \%$ injected in the muscle in the dose of $2.5 \mathrm{ml} / \mathrm{Kg}$ of body weight for five days after surgery, and anti-inflammatory Banamine (Flonexin Meglumine) injected in the dose of $1.1 \mathrm{ml} /$ $\mathrm{Kg}$ of body weight for three days after surgery by applications in the muscle.

\section{Histological and radiographic procedures}

At the end of the experimental periods of one, three and six months, the animals were killed with lethal injection of anesthetics (Dopalene). The bone piece with the perforation was removed and immediately placed in a formalin phosphate solution, buffered at $10 \%$ during a week for fixing. Thereafter, the epiphyses were radiographed by the digital method with aid of optical sensors and the Digora system for digital radiography (Sorodex Orion Corporation, Helsinki, Finland). The X-ray machine employed was model XR6010 (Gnatus Equipamentos Odontológicos, Ribeirão Preto, Brazil), at 
$60 \mathrm{kVp}$ and $10 \mathrm{~mA}$, the focus-film distance was $40 \mathrm{~cm}$ with an exposure time of 0.4 seconds. After exposure, the optical sensor was inserted in the reader of the Digora system, for achievement of the digital image. Next, they were decalcified in Morse solution (formic acid at $50 \%$ and sodium citrate at 20\%, 1:1), for approximately three months. The histotechnical procedures were performed and semi-serial cuts with 6-mm thickness were achieved and stained with hematoxylin and eosin.

\section{Histological analysis}

A descriptive analysis of the histological sections was performed with the light microscope Axioscop (Carl Zeiss, Germany), attempting to check the time sequence of the events that led to bone formation compared to the events in the control group.

\section{Radiographic analysis}

The amount of formed bone was evaluated on the digital images by two calibrated examiners who conducted both evaluations, with a 1-week interval between the first and second evaluations. The images were evaluated on a PC with 14-inch screen, with the Digora for Windows software. The same magnification and light conditions of the room were used throughout the study. The images were evaluated in both conventional or positive and inverted or negative modes.

The following scores were employed for evaluation (Figure 1):

0 - no bone formation

1 - bone formation at the borders of the defect

2 - bone formation ( $1 / 2$ of the defect filled)

3 - bone formation (3/4 of the defect filled)

4- bone formation completely filling the defect

The data achieved were compared at a probability level of $5 \%$ of error, on the statistical software Sigma Stat Jandel ${ }^{\mathrm{TM}}$ Scientific software for Windows.

\section{RESULTS}

\section{Radiographic results}

The Kappa test was applied for evaluation of intra and interexaminer agreement, by comparison of analysis of the positive and negative digital images, which revealed a remarkable agreement. Due to this agreement, the medians of each specimen were used for comparison between treatments and periods. The groups of each period were evaluated by the Kruskal-Wallis test. There were no statistically significant differences between the microgranular, macrogranular and control groups at all study periods.

The medians of the periods, regardless of the groups, were compared by the Kruskal-Wallis test, which revealed a statistically significant difference $(p=0.001)$. The Student-
Newman-Keuls test detected a statistically significant difference $(\mathrm{p}<0.05)$ in all comparisons between periods.

\section{Morphological results}

\section{Group 1: microgranular graft}

At one month, the surface of the defect showed newly formed and richly vascularized connective tissue, with bundles of collagen fibers and trabeculae of newly formed bone tissue from the outside to the center of the defect (Figure 2).Inside the bone marrow there were scattered fragments of the implanted material, surrounded by focuses of chronic inflammatory reaction with predominance of macrophages and a large amount of multinucleated giant cells, supported by a granulomatous tissue (Figure 3).

At three months, the defect was closed by a newly formed cortical plate slightly thinner than the remaining with normal periosteal tissue (Figure 4). In the bone marrow there were scarce residual fragments of the implanted material undergoing resorption, surrounded by a small population

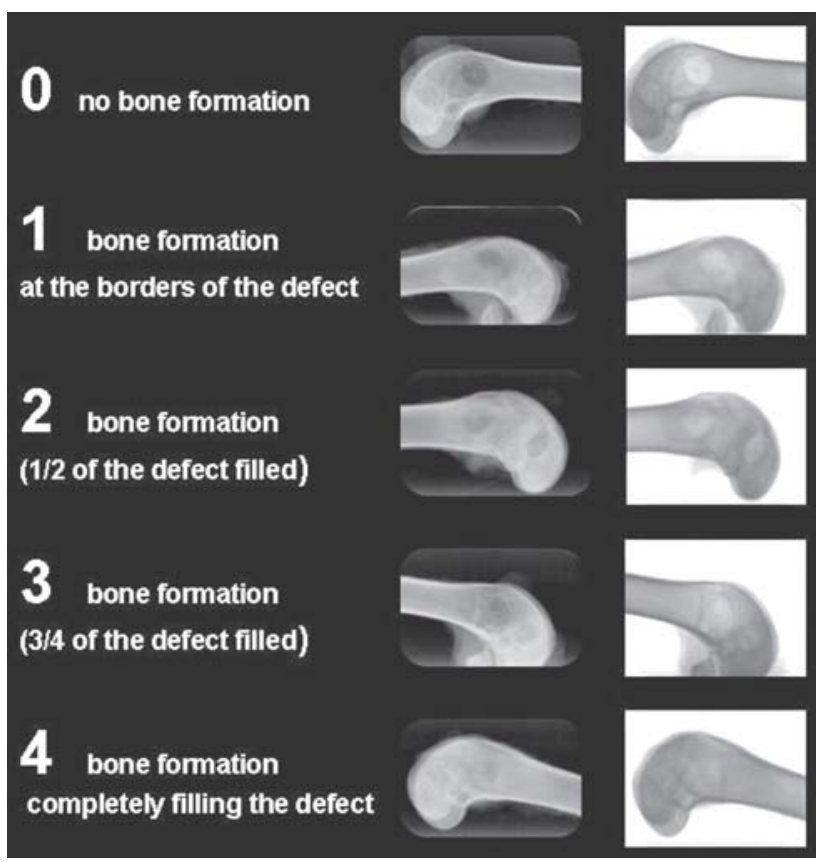

FIGURE 1

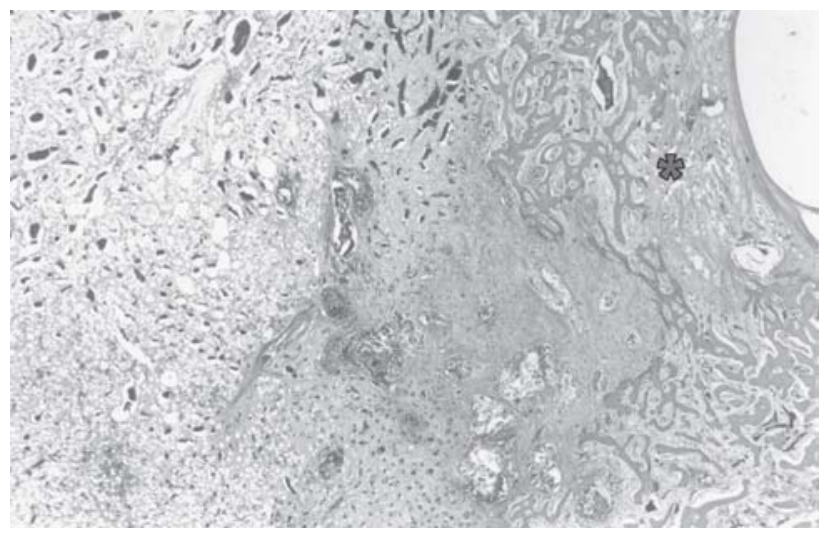

FIGURE2 
of chronic inflammatory cells.

At six months, the area of the defect showed to be closed by thin newly formed cortical bone with periosteum and normal bone marrow. In some cases, it was possible to notice, at the center of the bone marrow, traces of the implanted material undergoing resorption and surrounded by a wellvascularized granulomatous tissue with scattered chronic inflammatory cells (Figure 5).

Group 2: macrogranular graft

At one month, the central area of the defect showed newly formed connective tissue of a dense aspect and there was fresh formation of bone tissue at the peripheral portions. At the center of the bone marrow, small fragments of the implanted material in resorption process were observed, surrounded by chronic inflammatory infiltrate and presence of multinucleated giant cells (Figure 6).

At three months, the area of the defect was closed by a slim newly formed cortical bone (Figure 7). The bone marrow contained small and scattered residual fragments of implanted material, which were undergoing resorption and were surrounded by a mild chronic infiltrate rich in macrophages and multinucleated giant cells. In some cases, next to these particles in resorption, there was presence of newly formed bone.

At six months, the surface of the defect presented to be closed by newly formed cortical bone and respective periosteal tissue. The bone marrow also showed signs of normality, containing small fragments of the implanted

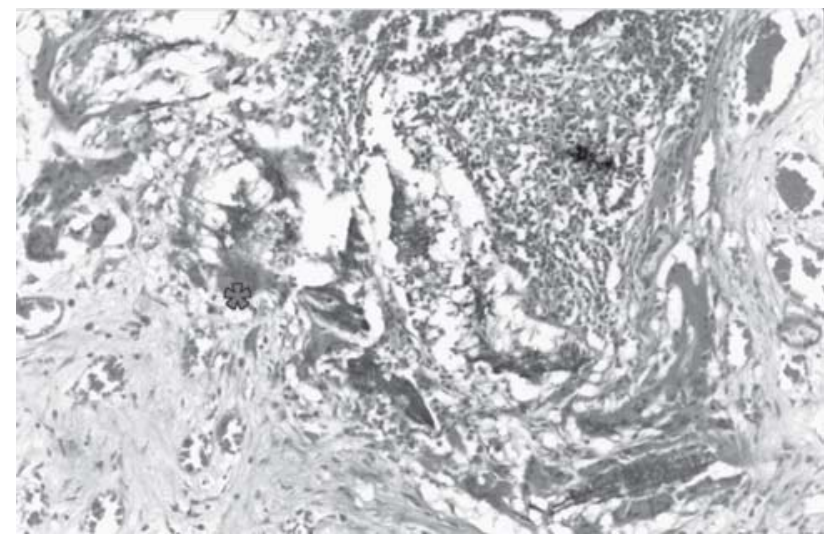

FIGURE 3

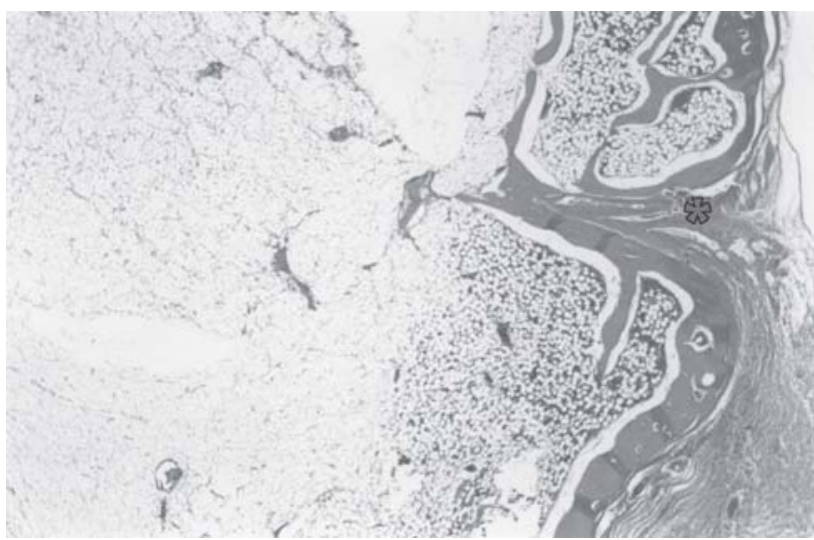

FIGURE4 material in process of resorption, surrounded by a chronic inflammatory infiltrate.

Group 3 -blood clot

After a month, the area of the defect was closed by dense newly formed connective tissue, together with a young cancellous bone proliferating towards the core of the defect. In the center of that young connective tissue, the presence of new bone formation points was observed (Figure 8).

At the 3-month period, the surface of the defect was closed by newly formed cortical bone thinner than the remaining, whose surface presented a dense and fibrous connective tissue rich in fibrocytes, compatible with periosteum and bone marrow with a normal aspect.

At six months, the area of the defect presented to be closed by newly formed cortical bone, thinner than the remaining, with normal periosteum and bone marrow (Figure 9).

\section{DISCUSSION}

In general, the bone defects exhibited significant new bone formation in all study groups, irrespective of the particle sizes.

In the experimental groups evaluated (macro and microgranular), at the three study periods, the presence of chronic inflammatory infiltrate was constant, usually

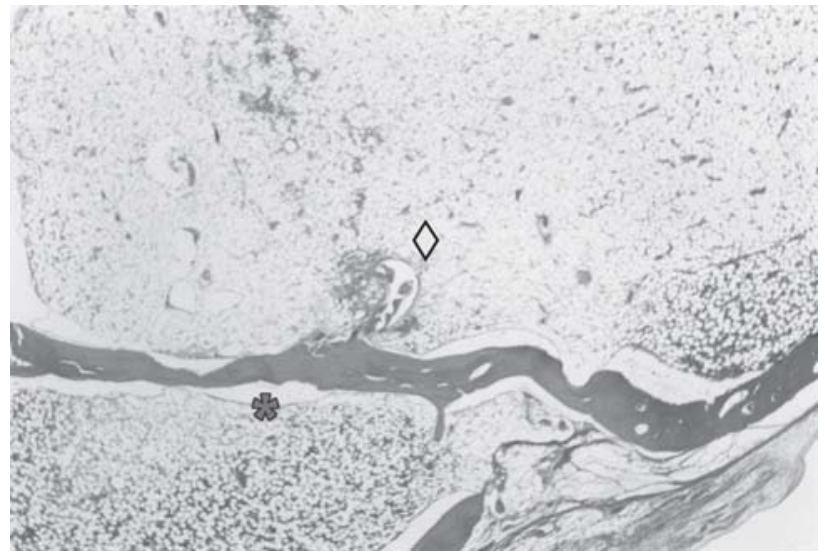

FIGURE 5

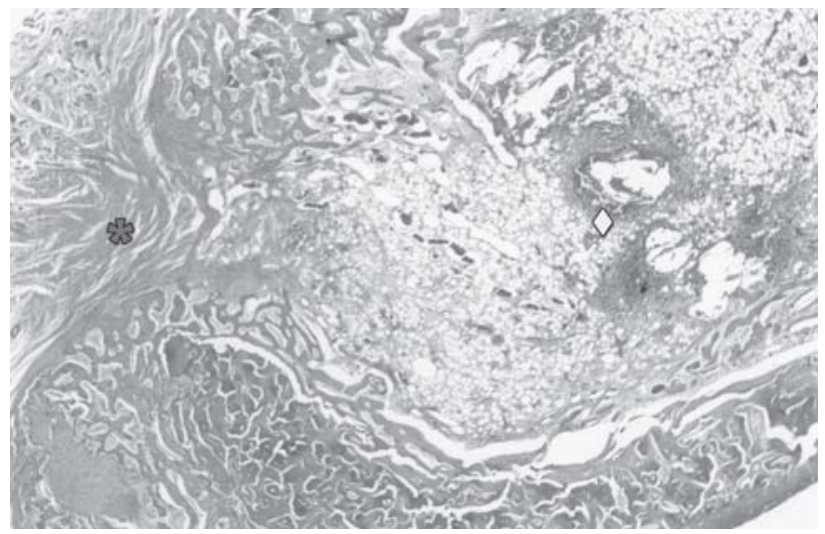

FIGURE 6 
discrete, with predominance of macrophages and multinucleated giant cells, characterizing a true foreign body granulomatous reaction, evidently containing scattered lymphocytes, suggesting that the particles of demineralized bovine bone matrix possibly present a low antigenic character in the rabbit, as already observed in other studies ${ }^{12}$.

Another finding that reinforces this statement are the studies on guinea pigs' skulls ${ }^{11}$, using particles of demineralized bovine bone matrix, blood clot and covered with lyophilized cortical bovine bone membrane, whose cellular response after a period of three to six months revealed new bone formation and absorption of the membrane by action of mononuclear cells similar to fibroblasts, which

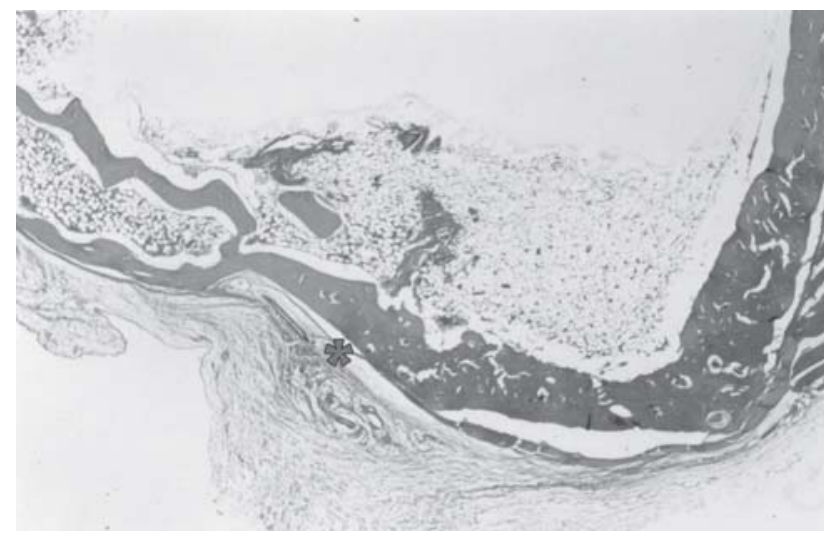

FIGURE7

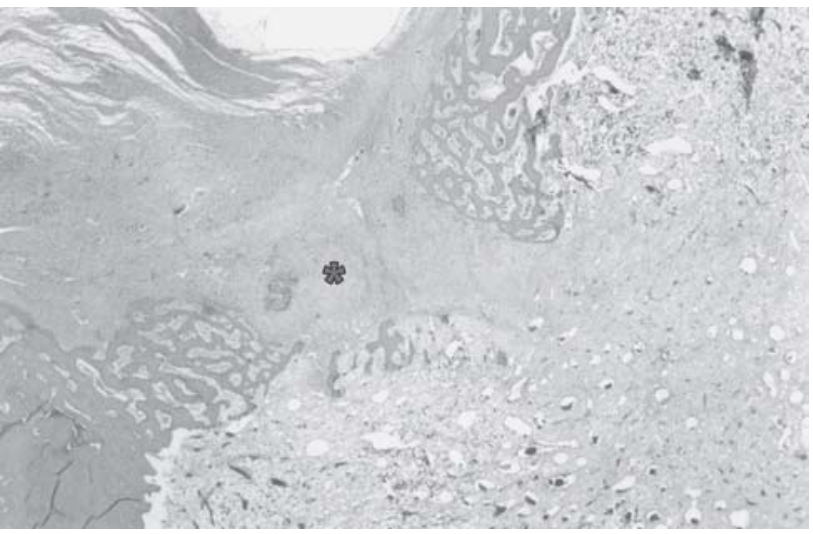

FIGURE8

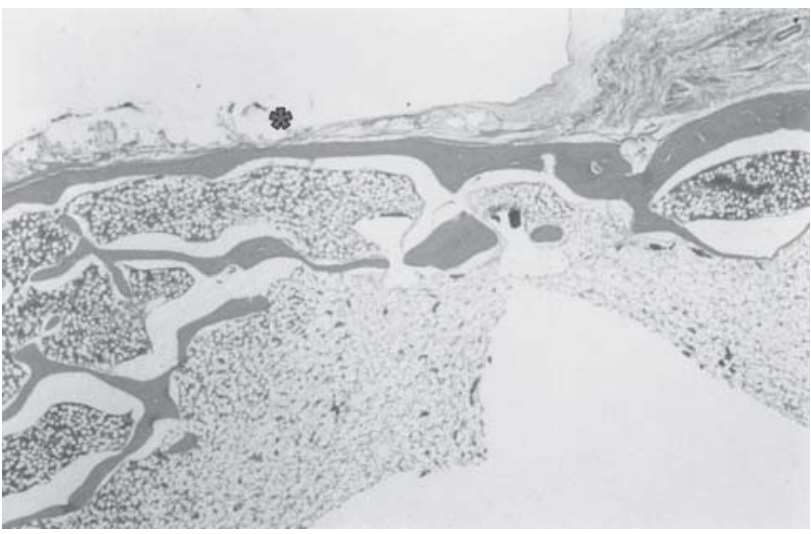

FIGURE 9 invade the interior of the membrane through porosities. Traces of implanted particles were involved by macrophages, suggesting the presence of some substance with antigenic power in the xenografts.

The presence of foreign body type granuloma around the mineralized particles has already been described in previous studies ${ }^{4}$. The cellular response with formation of a foreign body granuloma, compared with particles of inorganic bovine cortical bone in sizes of $250-1000 \mathrm{~mm}$ and 1000-2000mm, was similar to that observed in allogeneic and autogenous grafts in the subcutaneous tissue of mice and did not represent statistical difference according to their size $^{9}$.

The establishment of a foreign body granuloma may inhibit the new bone formation ${ }^{1}$, which was not observed in the present study, considering that the present chronic inflammatory reaction was discrete and did not interfere with the bone formation process in the groups grafted with micro and macrogranular bone matrix. However, the possible justification for the presence of a foreign body granulomatous reaction, despite mild, might be the incomplete decalcification of the material during its production, with permanence of matrix antigens or residual lipids, considering that the bovine cancellous bone is very rich in fat tissue, which could impair its thorough cleaning, even if drastic treatment is carried out with fat solvents like chloroform and ethylic ether. This affirmative is based on the fact that some multinucleated giant cells were intimately related to the surface of the particles of the grafted matrix, showing evidence of resorption activity.

The radiographic and histological analysis showed that most of the new bone was formed at the borders of the defects, indicating a doubtful osteoconductive ability of the xenograft, which did not differ from the control group, although the cancellous bovine bone matrix has a chemical composition of $90 \%$ of collagen type I and its structural characteristic is similar to the receptor bone. Many researchers state that the mentioned matrix does not have a significant amount of BMPs (bone morphogenetic proteins). However, around some macroparticles (3 months), there were small areas of focal new bone formation, suggesting the existence of bone induction factors in some segments of the structure of the xenograft, in an amount enough to induce some focal osteogenesis.

Comparison of the cellular response to the micro and macrogranular particles of demineralized bovine cancellous bone demonstrated that their size did not influence the receptor response. The process of repair of bone defects occurred in all groups, and there was no difference in the speed of new bone formation between the experimental and control groups. The formation of cancellous bone from the periphery to the center was started at the first month. In this sense, it is opportune to review the osteoinductive and osteoconductive capacity of granules of demineralized cancellous bovine bone that, according to the methodology, did not demonstrate inductive action ${ }^{2,7}$ compared to the blood clot (control). Concerning the osteoconductive capacity, there was no difference in relation to the blood 
clot, because in all groups the new bone formation occurred from the walls of the defect. Thus, it is possible to affirm that the granules of organic demineralized cancellous bovine bone matrix played only the role of bone filling material.

The difference between the control and experimental groups lies in the discrete chronic inflammatory infiltrate, suggesting that xenografts of this nature may even have residues of antigen components, justifying the chemotaxis of macrophages and appearance of multinucleated giant cells.

The ideal response of the receptor to the xenograft, originating from the bovine cancellous bone organic matrix, would be the absence of inflammatory reaction, especially at the longer periods, namely three and six months in the present study. The presence of inflammatory reaction may be linked to some inflammatory factors, as incomplete decalcification of the material, permanence of residual lipids or even immunopathological characteristic of the receptor itself; in the case of the rabbit, the response to implants of this nature is discrete, in agreement with other reports ${ }^{12}$.

The xenografts originated from the organic cancellous bovine bone matrix are an auxiliary alternative as bone filling material to repair major bone defects in oromaxillofacial surgeries. The control and complete elimination of possible traces of antigenic material that may trigger the persistence of inflammatory reaction is a concern, and, in this sense, the development of further studies will be an important contribution.

\section{REFERENCES}

1- Al Ruhaimi K.A. Bone graft substitutes: a comparative qualitative histologic review of current osteoconductive grafting materials. Int $\mathrm{J}$ Oral Maxillofac Implants. 2000;16(1):105-14.

2- Becker W, Urist MR, Tucker LM, Becker BE, Ochsenbein C. Human demineralized freeze-dried bone induced inadequate bone formation in athymic mice. A preliminary report. J Periodontol. 1995;66(9):822-8.

3- Damien C.J., Parsons J.R., Prewett A.B., Huismans F., Shors E.C., Holmes RE. Effect of demineralized bone matrix on bone growth within a porous material: a histologic and histometric study. J Biomater Appl. 1995;9(3):275-88

4- Gross J.S. Bone grafting materials for dental applications: a practical guide. Compend Contin Educ Dent. 1997;18(10):1013-36.

5- Kurashina K, Kurita H, Wu Q, Ohtsuka A, Kobayashi H. Ectopic osteogenesis with biphasic ceramics of hidroxyapatite and tricalcium phosphate in rabbits. Biomaterials. 2002;23:407-12.

6- Nimni M. E. Polypeptide growth factors: targeted delivery systems. Biomaterials. 1997; 8(18):1201-25.

7- Schwartz Z, Weesner T, Van Dijk S, Cochran DL, Mellonig JT, Lohmann CH, Carnes DL, et al. Ability of deproteinized cancellous bovine bone to induce new bone formation. J Periodontol. 2000;71(8):1258-69.

8- Sciadini MF, Dawson JM, Johnson KD. Evaluation of bovinederived bone with a natural coroal carrier as a bone-graft substitutes in a canine segmental defect model. J Orthop Res. 1997;15(6):84457.
9- Sicca CM, Oliveira RC, Silva TL, Cestari TM, Oliveira DT, Buzalaf, MAR, et al. Avaliação microscópica e bioquímica da resposta celular a enxertos de osso cortical bovino em subcutâneo de ratos. Efeito do tamanho da partícula. Rev FOB. 2000 Jan/Jun;8(1/2):1-10.

10- Tadjoedin ES, De Lange GL, Holzmann P, Kuiper L, Burger EH. Histological observations on biopsies harvested following sinus floor elevation using a bioactive glass material of narrow size range. Clin Oral Impl Res. 2000;11:334-444.

11- Taga R, Cestari TM, Silva TL, Stipp CM. Reparo de defeito perene em crânio de cobaia pela aplicação de osseobond. Rev Bras Implant. 1997;3(1):13-20.

12- Taga R, Hassunuma CY, Cestari TM, Ferreira PM. Destino de membrana cortical óssea bovina colocada em posição subperióstica na calvária de cobaias. Rev Bras Implant. 1997;3(6):24-9. 